\title{
PERAN SUPERVISOR DALAM MANAJEMEN KELAS
}

\author{
Endah Tri Wisudaningsih*
}

\begin{abstract}
Abstact
One indicator states that professional teachers / educators have the ability to manage classes, namely providing a conducive atmosphere for effective and efficient learning processes. If it is not yet conducive, then a teacher or lecturer must work optimally to master, regulate and improve, and create a conducive atmosphere so that the learning process can run optimally to achieve the desired learning goals.

Class management is not an easy and easy thing, let alone for teachers who have just fielded themselves into the world of education, for teachers who are already professional, they have felt how difficult it is to manage classes, but never teachers feel dry and then deter from managing classes every time they teach in class. The failure of a teacher to achieve teaching goals is in line with the inability of the teacher to manage the class, from failure it is achievement, learning of students is low, not in accordance with the standards or size limits that are determined, therefore classroom management is very important teacher competency mastered by the teacher within the framework of success teaching and learning process.
\end{abstract}

Keywords: professional teachers, and Class management

\section{PENDAHULUAN}

Salah satu indikator menyatakan bahwa guru/ pendidik yang profesional adalah memiliki kemampuan mengelola kelas yaitu menyediakan suasana yang kondusif untuk berlangsungnya proses pembelajaran yang efektif dan efisien. Apabila belum kondusif, maka seorang guru atau dosen harus berupayaseoptimal mungkin untukmenguasai, mengatur dan membenahi, serta menciptakan suasana kelasyang kondusif sehingga proses pembelajaran dapat berjalan secara optimal untuk mencapai tujuan pembelajaran yang diinginkan.

Pengelolaan kelas bukanlah hal yang mudah dan ringan jangankan bagi guru yang baru menerjunkan diri kedalam dunia

* Dosen Tetap Fak. Tarbiyah Institut Ilmu Keislaman Zainul Hasan Genggong 
pendidikan, bagi guru yang sudah profesionalpun sudah merasakan betapa sukarnya mengelola kelas, namun begitu tidak pernah guru merasa jemuh dan kemudian jera mengelola kelas setiapkali mengajar di kelas. Gagalnya seorang guru mencapai tujuan pengajaran sejalan dengan ketidakmampuan guru mengelola kelas, dari kegagalan itu adalah prestasi, belajar peserta didik rendah, tidak sesuai dengan standar atau batas ukuran yang ditentukan karena itu, pengelolaan kelas merupakan kopetensi guru yang sangat penting dikuasai oleh guru dalam kerangka keberhasilan proses belajar - mengajar.

Djamaroh menyebutkan " Masalah yang dihadapi guru, baik pemula maupun yang sudah berpengalaman adalah pengelolaan kelas. Aspek yang sering didiskusikan oleh penulis professional dan pengajar adalah juga pengelolaan kelas". Mengingat tugas utama dan paling sulit bagi pengajar adalah pengelolaan kelas, sedangkan tidak ada satu pendekatan yang dikatakan paling baik. Sebagian besar guru kurang mampu membedakan masalah pengajaran dan masalah pengelolaan. Masalah pengajaran harus diatasi dengan cara pengajaran dan masalah pengelolaan harus diatasi dengan cara pengelolaan. ${ }^{1}$

Masih banyak ditemukan guru yang mengajar tanpa perencanaan, terlambat dalam memulai pengajaran, tidak bergairah mengajar, kurang cakap mengajar, tidak membangkitkan kreatifitas peserta didik, tidak mempergunakan metode pembelajaran dengan tepat, kurang memperhatikan penggunaan media pembelajaran, tidak melaksanakan penilaian secara benar dan sebagainya. Dalam hal ini tentu tidak mengherankan bila situasi belajar mengajar tidak dapat dikelola dengan baik, sehingga peserta didik menjadi tidak bergairah belajar, pasif, tidak termotivasi, ramai di kelas, berbicara sendiri, mengantuk, mengganggu temannya, tidak menulis, bosan dan sebagainya. Untuk mengurangi/mencegah kekurangan- kekurangan tersebut diperlukan bantuan Pengawas dan Kepala Sekolah sebagai Supervisor.

Kepala sekolah dalam melaksanakan fungsinya sebagai supervisor, mencakup kegiatan-kegiatan yang bersangkutan dalam pembangkitan semangat, kerjasamaguru-guru, pemenuhanalat-alatdan perlengkapan sekolah demi kelancaran pengajaran, dalampraktekyang benar guru-guru tidak diperlakukan sebagai bawahan, melainkan sebagai

1 Djamarah, Syaiful Bahri. 2006. Strategi Belajar Mengajar. Jakarta. Rineka Cipta. H. 173 
rekan sejawat. Sudjana menjelaskan bahwa supervisi akademik diselenggarakan dengan tujuan membantu guru mengembangkan kemampuan profesionalnya dalam melaksanakan tugas pokok dan tanggung jawabnya yakni melaksanakan pembelajaran yang mendidik. Namun, pada kenyataannya pembinaan yang diberikan pengawas terhadap guru belum sesuai dengan harapan, yaitu terbangunnya komunikasi dengan pengawas baik berupa konsultatif ataupun bimbingan dalam mengatasi kendala yang dihadapi guru. Terlebih lagi dengan latar belakang pengawas yang sama sekali tidak memahami proses dan materi (content) pembelajaran, sehingga banyak guru yang tidak tertarik dengan kehadiran supervisor. ${ }^{2}$

\section{PEMBAHASAN}

\section{A. Pengelolaan kelas}

\section{Definisi}

Pengelolaan kelas adalah suatu usaha yang dilakukan oleh penanggung jawab kegiatan belajar mengajar atau yang membantu dengan maksud agar dicapai kondisi optimal sehingga dapat terlaksana kegiatan belajar seperti yang diharapkan. ${ }^{3}$ Pengelolaan kelas adalah kegiatan mengatur tata ruang kelas untuk pengajaran dan menciptakan iklim belajar mengajar yang serasi. ${ }^{4}$ Pengelolaan kelas adalah usaha dari pihak guru untuk menata kehidupan kelas yang dimulai dari perencanaan kurikulumnya, penataan prosedur dan sumber belajarnya, lingkungannya untuk memaksimalkan efesiensi, memantau kemajuan peserta didik dan mengantisipasi masalahmasalah yang mungkin timbul. ${ }^{5}$ Rachman menyatakan :"Manajemen Kelas adalah segala usaha guru dalam upayanya menciptakan dan memelihara kondisi kelas yang efektif dan menyenangkan serta dapat memotivasi peserta didik untuk belajar dengan baik sesuai dengan kemampuannya". ${ }^{6}$

2 Sudjana, Nana \& Ibrahim. 2011. Penelitian Dan Penilaian Pendidikan. Bandung : Sinar Baru. h. 56

3 Suharsimi Arikunto, Pengelolaan Kelas dan peserta didik : 1987 : 68

4 E. Komar dan Uus Rusnadi. Pengelolaan Belajar Dan Kelas, 1993

5 Cece Wijaya dan A. Tabrani Rusyar, Kemampuan Dasar Guru dalam Proses Belajar Mengajar, 1992 : 113

6 Rachman, Maman. 1998. Manajemen Kelas. Jakarta: Departemen Pendidikan dan Kebudayaan Direktorat Jenderal Pendidikan Tinggi. h. 8 


\section{Tujuan Pengelolaan kelas}

Secara khusus, tujuan pengelolaan kelas dalam pandangan Usman adalah mengembangkan kemampuan peserta didik dalam menggunakan alat-alat belajar, menyediakan kondisi-kondisi yang memungkinkan peserta didik bekerja dan belajar serta membantu peserta didik untuk memperoleh hasil yang diharapkan. ${ }^{7}$

Pengelolaan kelas dimaksudkan untuk menciptakan kondisi dalam kelompok kelas yang berupa lingkungan kelas yang baik, yang memungkinkan peserta didik berbuat sesuai dengan kemampuannya. Tujuan pengelolaan kelas pada hakikatnya telah terkandung dalam tujuan pendidikan. Menurut Cece Wijaya menyebutkan tujuan pengelolaan kelas adalah :

1) Agar pengajaran dapat dilakukan secara maksimal sehingga tujuan pengajaran dapat dicapai secara efektif dan efisien.

2) Untuk memberi kemudahan dalam usaha memantau kemajuan peserta didik dalam pelajarannya. Dengan pengelolaan kelas, guru mudah melihat dan mengamati setiap kemajuan yang dicapai peserta didik, terutama peserta didik yang tergolong lamban.

3) Untuk memberi kemudahan dalam mengangkat masalahmasalah penting untuk dibicarakan di kelas untuk perbaikan pengajaran pada masa mendatang. ${ }^{8}$

Menurut pendapat Dirjen PUOD dan Dirjen Dikdasmen tujuan manajemen kelas di antaranya adalah :

a. Mewujudkan situasi dan kondisi kelas, baik sebagai lingkungan belajar maupun sebagai kelompok belajar, yang memungkinkan peserta didik untuk mengembangkan kemampuannya semaksimal mungkin; b. Menghilangkan berbagai hambatan yang dapat menghalangi terwujudnya interaksi pembelajaran; c. Menyediakan dan mengatur fasilitas serta perabot belajar sesuai dengan lingkungn sosial, emosional dan intelektual peserta didik dalam kelas; d. Membina dan membimbing peserta didik sesuai dengan latar belakang sosial, ekonomi, budaya, serta sifat-sifat individualnya. ${ }^{9}$

Dari pengertian di atas secara umum tujuan manajemen kelas

7 Mujamil Qomar, hlm. 284

8 Cece Wijaya dan Tabrani Rusyan, Kemampuan Dasar Guru dalam Proses Belajar Mengajar, 1992., hlm. 144.

9 Rachman, Maman. 1998. Manajemen Kelas. Jakarta: Departemen Pendidikan dan Kebudayaan Direktorat Jenderal Pendidikan Tinggi. h. 12 
adalah menyediakan dan menggunakan fasilitas kelas untuk bermacam-macam kegiatan belajar dan mengajar agar mencapai hasil yang baik. Sedangkan tujuan khususnya adalah mengembangkan kemampuan peserta didik dalam menggunakan alat-alat belajar, menyediakan kondisi-kondisi yang menmungkinkan peserta didik bekerja dan bekerja, serta membantu peserta didik untuk memperoleh hasil yang di harapkan.

\section{Bentuk Operasional Pengelolaan Kelas}

Bentukkegiatan mengelola kelas dilakukan secara fisik maupun psikis.

Kegiatanmengelola kelas dilakukan secara fisik (pengaturan peserta didik)berupa :

1) Mengatur ventilasi dalam kelas,

2) Mengatur pencahayaan

3) Mengatur kenyamanan peserta didik

4) Mengatur letak duduk

5) Mengatur penempatan peserta didik

Kegiatan pengelolaan kelas secara psikhis (kondisi emosional) berupa :

1) Mengatur tingkah laku

2) Mengatur kedisiplinan

3) Mengatur minat

4) Gairah belajar

5) Mengatur dinamika kelompok

\section{Beberapa Masalah Pengelolaan Kelas}

Pengelolaan kelas berbeda dengan pengelolaan pembelajaran. Pengelolaan pembelajaran lebih menekankan pada kegiatan perencanaan, pelaksanaan, evaluasi dan tindak lanjut dalam suatu pembelajaran. Sedangkan pengelolaan kelas lebih berkaitan dengan upaya-upaya untuk menciptakan dan mempertahankan kondisi yang optimal bagi terjadinya proses belajar (pembinaan rapport, penghentian perilaku peserta didik yang menyelewengkan perhatian kelas, pemberian ganjaran, penyelesaian tugas oleh peserta didik secara tepat waktu, penetapan norma kelompok yang produktif), didalamnya mencakup pengaturan orang (peserta didik) dan fasilitas. 
Terdapat dua macam masalah pengelolaan kelas, yaitu : Masalah Individualdan Masalah Kelompok. ${ }^{10}$

Masalah Individual :

a. Attention getting behaviors (pola perilaku mencari perhatian).

b. Power seeking behaviors (pola perilaku menunjukkan kekuatan).

c. Revenge seeking behaviors (pola perilaku menunjukkan balas dendam).

d. Helplessness (peragaan ketidakmampuan).

Ada empat teknik sederhana untuk mengenali adanya masalahmasalah perorangan seperti diuraikan diatas pada diri para peserta didik.

1. jika guru merasa terganggu (atau bosan) dengan tingkah laku seorang peserta didik, hal itu merupakan tanda bahwa peserta didik yang bersangkutan mungkin mengalami masalah mencari perhatian.

2. jika guru merasa terancam (atau merasa dikalahkan), hal itu merupakan tanda bahwa peserta didik yang bersangkutan mungkin mengalami masalah mencari kekuasaan.

3. jika guru merasa amat disakiti, hal itu merupakan tanda bahwa peserta didik yang bersangkutan mungkin mengalami masalah menuntut balas.

4. jika guru merasa tidak mampu menolong lagi, hal itu merupakan tanda bahwa peserta didik yang bersangkutan mungkin mengalami masalah ketidakmampuan. Ditekankan, guru hendaknya benarbenar mampu mengenali dan memahami secara tepat arah tingkah laku peserta didik-peserta didik yang dimaksud (apakah tingkah laku peserta didik itu mengarah ke mencari perhatian, mencari kekuasaan, menuntut balas, atau memperlihatkan ketidakcampuran) agar guru itu mampu menangani masalah peserta didik secara tepat pula.

Masalah Kelompok :

Dikenal adanya tujuh masalah kelompok dalam kaitannya dengan pengelolaan kelas:

1. Kekurang-kompakan

2. Kekurangmampuan mengikuti peraturan kelompok

3. Reaksi negatif terhadap sesama anggota kelompok

4. Penerimaan kelas (kelompok) atau tingkah laku yang menyimpang

${ }^{10}$ Ahmad Rohani. Pengelolaan Pengajaran. Jakarta : Rineka Cipta, 2010. H. 145-146. 
5. Kegiatan anggota atau kelompok yang menyimpang dari ketentuan yang telah ditetapkan, berhenti melakukan kegiatan atau hanya meniru-niru kegiatan orang (anggota) lainnya saja

6. Ketiadaan semangat, tidak mau bekerja, dan tingkah laku agresif atau protes

7. Ketidakmampuan menyesuaikan diri terhadap perubahan lingkungan

\section{Pendekatan Pendekatan dalam Manajemen Kelas}

Keharmonisan hubungan guru dan anak didik, tingginya kerjasama diantara peserta didik tersimpul dalam bentuk interaksi. Lahirnya interaksi yang optimal bergantung dari pendekatan yang guru lakukan dalam rangka pengelolaan kelas. (Djamarah 2006:179) Menurut pendapat Rachman, pendekatan yang dapat dilakukan dalam manajemen kelas diantaranya adalah: ${ }^{11}$

1) Pendekatan Otoriter

2) Pendekatan Intimidasi

3) Pendekatan permisif

4) Pendekatan buku masak

5) Pendekatan instruksional

6) Pendekatan pengubahan perilaku

7) Pendekatan iklim sosio-emosional

8) Pendekatan proses kelompok

9) Pendekatan eklektik

10) Pendekatan analitik pluralistik

\section{Langkah Manajemen Kelas}

Serangkaian langkah kegiatan yang harus dilakukan dalam manajemen kelas mengacu kepada dimensi pencegahan (Preventif) dan dimensi penyembuhan (Kuratif): ${ }^{12}$

a) Dimensi Pencegahan (Preventif)

Adapun langkah-langkah pencegahan sebagai berikut :

(1) Peningkatan kesadaran diri sebagai guru

(2) Peningkatan kesadaran peserta didik

${ }^{11}$ Rachman, Maman. 1998. Manajemen Kelas. Jakarta: Departemen Pendidikan dan Kebudayaan Direktorat Jenderal Pendidikan Tinggi. h. 35-80.

${ }^{12}$ Mulyadi, Classroom Manajemen, UIN Malang Press, 2009. H. 19-26. 
(3) Sikap polos dan tulus dari guru

(4) Mengenal dan memerlukan alternatif pengelolalaan.

(5) Menciptakan kontrak sosial

b) Dimensi Penyembuhan (Kuratif)

Pada dasarnya prosedur dimensi penyembuhan dapat dilakukan melalui langkah-langkah sebagai berikut:

(1) Mengindentifikasi masalah

(2) Menganalisis masalah

(3) Menilai alternatif-alternatif pemecahan

(4) Mendapatkan balasan

\section{B. Fungsi dan Tujuan Supervisi Pendidikan dalam manajemen kelas}

\section{Fungsi Supervisi Pendidikan}

Di awal pembahasan telah disebutkan bahwa fungsi Supervisi Pendidikan adalah:

1) Fungsi Penelitian

2) Fungsi Penilaian

3) Fungsi Perbaikan

4) Fungsi Peningkatan

\section{Tujuan Supervisi Pendidikan}

Tujuan supervisi pendidikan dalam kaitannya dengan manajemen kelas adalah :

a. Membantu guru agar lebih mengerti atau menyadari tujuan-tujuan pendidikan di sekolah dan fungsi sekolah dalam usaha mencapai tujuan pendidikan itu.

b. Membantu guru agar lebih menyadari dan mengerti kebutuhan dan masalah-masalah yang dihadapi peserta didiknya, supaya dapat membantu peserta didiknya lebih baik lagi.

c. Membantu guru meningkatkan kemampuan penampilannya di depan kelas

d. Membantu guru baru dalam orientasinya supaya cepat dapat menyesuaikan diri dengan tugasnya dan dapat mendayagunakan kemampuannya secara maximal.

e. Membantu guru menemukan kesulitan belajar murid-muridnya 
dan merencanakan tindakan-tindakan perbaikannya

Dalam melaksanakan tugasnya bidang supervisi akademik, kompetensi yang harus dimiliki oleh seorang pengawas antara lain:13 - Membimbing guru dalam merefleksi hasil-hasil yang dicapai, kekuatan, kelemahan, dan hambatan yang dialami dalam pembelajaran yang telah dilaksanakan.

- Membantu guru dalam mengelola, merawat, mengembangkan, dan memanfaatkan fasilitas pembelajaran yang berkaitan dengan mata pelajaran SD/mata pelajaran sekolah menengah yang termasuk dalam rumpunnya.

Beberapa tujuan supervisi di atas akan menjadi efektif bilamana kepala sekolah sebagai supervisor pendidikan memberikan peluang yang lebih banyak kepada para guru dalam mengembangkan kemampuan profesionalnya, baik melalui belajar mandiri atau melalui pelatihan dan bentuk pengembangan lainnya yang dilakukan oleh lembaga. Kepala sekolah harus memberikan peluang dan kesempatan sebesar-besarnya sehingga peningkatan kemampuan merupakan suatu kebutuhan yang harus di penuhi. Tujuan-tujuan di atas menjadi pedoman supervisor, khususnya kepala sekolah dalam menjalankan sepervisinya sehingga beragam kegiatan itu dapat menjadi satu arah tertuju pada tujuan yang ingin dicapai.

Kata kunci dari supervisi ialah memberikan layanan bantuan kepada guru-guru, maka tujuan supervisi adalah memberikan layanan dan bantuan untuk mengembangkan situasi belajar mengajar yang dilakukan guru di kelas yang bertujuan untuk meningkatkan kualitas belajar peserta didik. Tingkat keefektifan kelas dipengaruhi oleh kinerja guru dalam mengelola kelas. Keefektifan guru berpengaruh terhadap pengajaran, sehingga diperlukan guru yang termotivasi dan kompeten dalam mengelola kelas. Keefektifan kelas dipengaruhi oleh kepala sekolah dalam memberikan supervisinya kepada guru. Dengan demikian kepala sekolah harus tanggap untuk memberi bantuan kepada guru yang mempunyai masalah atau problema yang berhubungan dengan masalah pengaturan manajemen kelas.

Sementara N. A. Amatembun mengemukakan bahwa aktivitas kepala sekolah dalam prosesnya sebagai supervisor pendidikan

${ }^{13}$ Lihat PP Nomor 74 Tahun 2008 Tentang Guru dan Pengawas. Lihat juga Peraturan Menteri Pendidikan Nasional No. 12 Tahun 2007 tentang Standar Pengawas Sekolah/Madrasah 
meliputi: a) penelitian (research); b) penilaian (evaluation); c) perbaikan (improvement); d) peningkatan (development); d) membantu (assistenace) dan e) bekerjasama (cooperation). ${ }^{14}$

\section{Kontribusi Supervisor/ Kepala Sekolah Terhadap Upaya Guru Dalam Manajemen Kelas}

Kontribusi Supervisor/ Kepala Sekolah dalam upaya membantu guru dalam manajemen kelas dapat dilakukan melalui :

\section{Pengaturan Fisik (Penataan Ruang Kelas)}

Lingkungan fisik tempat belajar mempunyai pengaruh penting terhadap hasil pembelajaran. Lingkungan fisik yang menguntungkan dan memenuhi syarat akan mendukung terhadap peningkatan identitas pembelajaran peserta didik dan berpengaruh positif terhadap pencapaian tujuan pengajaran. Guru harus dapat menciptakan lingkungan kelas yang mampu membantu perkembangan peserta didik. Melalui teknik motifasi yang akurat, guru dapat memberikan pengaruh terhadap iklim kelas yang sehat. Kondisi dan lingkungan hendaknya menjadi perhatian dan kepedulian guru agar peserta didik dapat belajar secara lebih baik

Pengarahan ini erat kaitannya dengan manajemen kelas, yaitu memadukan semua upaya sehingga terjadi keserasian dalam seluruh kegiatan dan mempermudah pencapaian tujuan. Penataan ruangan kelas sepatutnya disesuaikan dengan metode pembelajaran yang dilaksanakan, apakah secara perorangan, kelompok atau klasikal. Penataan ruangan kelas pada umumnya disesuaikan dengan kepentingan pembelajaran klasikal melalui proses penyampaina materi pembelajaran dengan cara imposisi. Dengan demikian kemudahan komonikasi hanya berlaku pada komonikaasi satu arah atau dua arah.

Dalam Pengaturan fisik (Penataan Ruang Kelas) ini meliputi;

a. Pengelolaan tempat belajar; Pengaturan tempat duduk (meja dan kursi)

b. Pengaturan alat-alat pengajaran;

1. Perpustakaan kelas

2. Alat peraga / media pengajaran

3. Papan tulis, kapur tulis, dan lain-lain

4. Papan presensi anak didik

${ }^{14}$ Amatembun, N. A. 1992. Manajemen Kelas. IKIP Bandung. H. 3-4. 
c. Penataan keindahan dan kebersihan kelas dan kenyamanan peserta didik;

1. Hiasan dinding

2. Penempatan lemari

3. Pemelihara kebersihan

4. Ventilasi dan tata cahaya.

d. Pengaturan anak didik/ penempatan letak dudukpeserta didik Dapat dilakukan secara perorangan, berpasangan, kelompok, sesuai keterlibatan peserta didikpeserta didik, interaksi belajar, dan ketersedian sarana dan prasarana serta karakteristik peserta didik.

e. Pengelolaan Isi/ Materi Pembelajaran

f. Pengelolaan Sumber Belajar

\section{Pengaturan Psikis}

a. Penerapan Prinsip Belajar Sambil Berbuat

Dalam hal ini supervisor/ kepala sekolah dituntut untuk terjun di kelas untuk memberikan contoh. Prinsip belajar sambil berbuat atau belajar sambil mengalami bukan semata - mata berkaitan dengan bentuk belajar ketrampilan, tetapi juga berkaitan dengan bentuk belajar yang lain, yaitu belajar verbal, belajar konsep dan belajar pemecahan masalah, meskipun bentuk perbuatannya disesuaikan dengan bentuk belajar yang dilakukan. Bukan hanya peserta didik, gurupun ketika mengajar hendaknya sambil berbuat dan memberikan keteladanan. Mengajar dengan perbuatan yang dilakukan tubuh lebih mengena dari perkataan. Ada ungkapan perbuatan berbicara lebih tepat dari pada perkataan, belajar berjalan dengan berjalan, belajar berenang dengan beenang, belajar memanah dengan memanah. Artinya belajar lebih baik dari pada dipraktekan dalam bentuk perbuatan kata - kata.

b. Penerapan Kedisiplinan Guru

Supervisor/ kepala sekolah berusaha dan mampu menciptakan disiplin kinerja guru. Imron (1995) menyatakan bahwa disiplin kinerja mengajar guru adalah suatu keadaan tertib dan teratur yang dimiliki guru dalam bekerja disekolah, tanpa ada pelanggaran - pelanggaran yang merugikan baik langsung maupun tidak langsung terhadap dirinya, teman sejawatnya dan terhadap 
sekolah secara keseluruhan. Oleh karenanya, terdapat tiga model yang harus dikembangkan diantaranya :

1) Disiplin yang dibangun berdasarkan konsep otoritarian yaitu mentaati segala peraturan yang diberikan sekolah tanpa menyumbangkan banyak pikiran.

2) Disiplin yang dibangun berdasarkan konsep permissive yaitu segala peraturan didalam kelas dan sekolah yang dilonggarkan dan tidak perlu mengikat pada guru.

3) Disiplin yang dibangun berdasarkan kebebasan yang terkendali yaitu memberikan kebebasan kepada guru untuk berbuat dan dapat dipertanggung jawabkan.

c. Penerapan Keteladanan Guru

Sebagai teladan, tentu saja pribadi dan apa yang dilakukan guru akan mendapat sorotan peserta didik serta orang disekitar lingkungannya yang menganggap atau mengakui sebagai guru. Sehubungan itu, beberapa hal dibawah ini perlu mendapat perhatian para guru.

1) Sikap dasar

2) Bicara dan gaya bicara

3) Kebiasaan bekerja

4) Sikap melalui pengalaman dan kesalahan

5) Pakaian

6) Hubungan kemanusiaan

7) Proses berfikir

8) Perilaku neorotis

9) Selera

10) Keputusan

11) Kesehatan

12) Gaya hidup secara umum

d. Penerapan Kedisiplinan Peserta Didik

Tugas guru dalam pembelajaran tidak terbatas pada penyampaian materi pembelajaran, tetapi lebih dari itu guru harus membentuk kompetensi dan pribadi peserta didik. Oleh karena itu, supervisor harus senantiasa mengawasi perilaku peserta didik, terutama pada jam - jam sekolah, agar tidak terjadi penyimpangan perilaku atau tindakan yang indisiplin. Untuk kepentingan tersebut dalam rangka mendisiplinkan pserta didik, guru harus mampu menjadi pembimbing, contoh atau teladan, pengawas dan perilaku peserta 
didik.

Sebagai pegawas berupaya membimbing guru dan bekerjasama dengan guru untuk membimbing dan mengarahkan perilaku peserta didik kearah yang positif, dan menunjang pembelajaran, sebagai contoh dan teladan, guru harus memperlihatkan perilaku disiplin yang baik kepada peserta didik, karna bagaimana peserta didik akan berdisiplin kalau gurunya tidak menunjukkan sikap disiplin.

Sebagai pengawas, supervisor senantiasa mengawasi seluruh perilaku peserta didik, terutama pada jam - jam efektif sekolah, sehingga kalau terjadi pelanggaran terhadap disiplin, dapat segera diatasi. Sebagai pengendali, guru harus mampu mengendalikan perilaku peserta didik disekolah. Dalam hal ini guru harus mampu secara efektif menggunakan alat pendidikan secara tepat waktu dan tepat sasaran. Baik memberikan hadiah maupun hukuman terhadap peserta didik.

Sementara Rachman menyatakan bahwa: "kondisi sosio-emosional itu meliputi ; tipe kepemimpinan guru, sikap guru, suara guru dan pembinaan hubungan baik. "15 Secara lebihrincisebagai berikut:

1) Tipe kepemimpinan, artinya peranan dan tipe kepemimpinan guru akan mewarnai suasana emosional di dalam kelas.

2) Sikap guru, artinya perilaku-perilaku guru yang ditampilkan dalam menghadapi setiap peserta didik, baik yang bermasalah maupun yang tidak mermasalah.

3) Suara guru, artinya bagaimana guru mengeluarkan suara ketika sedang menyampaikan pelajaran kepada peserta didik.

4) Pembinaan hubungan baik, artinya guru perlu melakukan pembinaan hubungan baik dengan setiap peserta didik.

\section{Langkah-langkah Manajemen Kelas}

Tindakan supervisor dalam membantu guru melakukan kegiatan manajemen kelas perlu dilaksanakan secara sistematis, berdasarkan langkah-langkah yang sudah ditentukan bagi terciptanya kondisi optimal serta mempertahankannya supaya proses pembelajaran dapat berlangsung secara efektif dan efisien. Serangkaian langkah kegiatan dalam manajemen kelas mengacu kepada dimensi pencegahan

${ }^{15}$ Rachman, Maman. 1998. Manajemen Kelas. Jakarta: Departemen Pendidikan dan Kebudayaan Direktorat Jenderal Pendidikan Tinggi. H. 131-141. 
(Preventif) dan dimensi penyembuhan (Kuratif):

a) Dimensi Pencegahan (Preventif)

Supervisor membantu tindakan guru dalam mengatur peserta didik dan peralatan serta format pembelajaran yang tepat sehingga menumbuhkan kondisi yang dapat mendukung bagi berlangsungnya proses pembelajaran yang efektif dan efisien.

Adapun langkah-langkah pencegahan dari supervisor kepada guru sebagai berikut :

(1) Peningkatan kesadaran diri sebagai guru

Peningkatan kesadaran diri sebagai guru merupakan langkah yang strategis dan mendasar, karena dengan dimilikinya kesadaran ini akanmeningkatkan rasa tanggung jawab dan rasa memiliki yang merupakan modal dasar bagi guru dalam melaksanakan tugasnya.

(2) Peningkatan kesadaran peserta didik

Kurangnya kesadarannya peserta didik akan menumbuhkan sikap suka marah, mudah tersinggung, yang pada gilirannya memungkinkan peserta didik melakukan tindakan-tindakan yang kurang terpuji dan dapat mengganggu proses pembelajaran.

(3) Sikap polos dan tulus dari guru

Peran guru sangat besar dan sangat berpengaruh dalam menciptakan kondisi optimal proses pembelajaran. Oleh karena itu supervisor mengingatkan, guru hendaknya bersikap polos dan tulus terhadap para peserta didik.

(4) Mengenal dan memerlukan alternatif pengelolalaan.

Untuk mengenal dan menemukan alternatif pengelolaan, berupa :

(a) Melakukan identifikasi berbagai berbagai penyimpangan tingkah laku peserta didik yang sifatnya individual maupun kelompok;

(b) Mengenal berbagai pendekatan dalam manajemen kelas;

(c) Mempelajari pengalaman guru-guru lainnya gagal atau berhasil sehingga dirinya memiliki alternatif yang bervariasi dalam menanganai berbagai masalah manajemen kelas.

(5) Menciptakan kontrak sosial

Penciptakan kontrak sosial pada dasarnya berkaitan dengan 
"standar tingkah laku". Standar tingkah laku ini dibentuk melalui kontrak sosial antara sekolah/guru dan peserta didik.

b) Dimensi Penyembuhan (Kuratif)

Dalam hal ini supervisor membantu guru dalam menumbuhkan kesadaran akan penyimpangan yang dibuat dan akhirnya akan menimbulkan kesadaran dan tanggung jawab untuk memperbaiki diri melalui kegiatan-kegiatan yang direncakan serta dapat dipertanggung jawabkan.

Pada dasarnya prosedur dimensi penyembuhan dapat dilakukan melalui langkah-langkah sebagai berikut:

(1) Mengindentifikasi masalah

Supervisor membantu guru dalam mengidentifikasi jenis-jenis penyimpangan sekaligus mengetahui latar belakang yang membuat peserta didik melakukan penyimpangan tersebut.

(2) Menganalisis masalah

Supervisor membantu guru dalam menganalisi penyimpangan peserta didik dan menyimpulkan latar belakang serta sumbersumber dari penyimpangan itu.

(3) Menilai alternatif-alternatif pemecahan

Supervisor membantu guru dalam menilai dan melatih alternatif pemecahan masalah berdasarkan sejumlah alternatif yang telah disusun. Sesudah terpilih alternatif pemecahan yang dianggap tepat, selanjutnya guru melaksanakan alternatif pemecahan itu.

(4) Mendapatkan balasan

Supervisor membantu guru dalam langkah monitoring, melakukan kegiatan kilas balik. Kegiatan kilas balik ini dimaksudkan untuk menilai keampuhan pelaksanaan dan alternatif pemecahan yang dipilih untuk mencapai sasaran yang sesuai dengan yang direncanakan. Informasi yang diperoleh dari balikan ini merupakan hal yang sangat berguna untuk menilai program, akhirnya merupakan dasar melakukan perbaikan program.

\section{Temuan Lapangan}

Temuan pada salah satu sekolah bahwa, kepengawasan dilapangan 
belum maksimal dilaksanakan. Pengawas lebih enjoy berkantor atau kepentingan yang lain daripada datang ke sekolah. Pengawas datang dalam satu semester maksimaldua kali dan itupun hanya beberapa saat (tidak lebih dari dua jam). Pengawas datang hanya mengawasi (menanyakan) aspek administrasi saja dan mengesampingkan aspek akademiknya. Pengawas belum pernah masuk kelas untuk memberikan bantuan kepada guru dalam hal pengelolaan kelas, kesulitan kesulitan dalam menghadapi peserta didik, kekurangan kekurangan yang dimiliki guru yang harus diselesaikan dan lain lain. Pengawasan terhadap guru dalam pengelolaan kelas sering dan hanya dilakukan oleh kepala sekolah. Berbagai persoalan yang dihadapi oleh guru secara langsung diajukan, diketahui dan diselesaikan oleh kepala sekolah bersama guru. Bagaimana mungkin pada sekolah yang SDM nya pas pasan untuk bisa meningkatkan mutu menyamai sekolah yang lain sementara kepengawasan hanya mengandalkan dan dilakukan oleh kepala sekolah yang ada?

\section{E. Analisa}

Berikut ini adalah analisis yang penulis kemukakan mengenai kontribusi supervisor terhadap guru dalam manajemen kelas:

1. Kekuatan:

Pengawas leluasa memilih teori pendekatan apapun yang bisa diaplikasikan dalam hal pengelolaan kelas pada sekolah dan guru yang dituju.

2. Kelemahan

Jumlah sekolah dan guru yang diawasi terlalu banyaksertatuntutan oleh atasan untuk membuat administrasi yang rinci, membuat pengawas tidak bisa untuk sering melakukan pembinaan kepada sekolah yang diawasi.

3. Peluang

Peluang bagi pengawas untuk menemukan dan mengembangkan gagasan tentang manajemen kelas serta merupakan lahan peningkatan karir.

4. Ancaman

Ketidak profesionalanpengawas dalam menjalankan tugasnya, maka akan dibenci oleh kepala sekolah dan guru yang diawasi. Supervisi kepala sekolah sangat memberikan kontribusi terhadap 
kemampuan guru dalam manajemen kelas. Proses pembelajaran tidak akan berjalan dengan baik atau mengalami kemunduran apabila hanya bertumpu pada penilain dan dukungan yang dilakukan oleh supervisor, tanpa didukung oleh seorang supervisor aktiv yang dalam hal ini adalah kepala sekolah yang mampu membina dan mengarahkan para guru untuk melaksanakan proses pembelajaran yang baik dan berhasil. Sudah tentu bahwa kemajuan atau kemunduran suatu proses pembelajaran yang dilaksanakan merupakan tanggung jawab guru dan kepala sekolah.

Kontribusi supervisi kepala sekolah terhadap upaya guru dalam manajemen kelas, yaitu dalam hal perbaikan pembelajaran, secara singkatnya; guru sebagai orang yang secara langsung dilapangan memperbaiki pembelajaran tersebut, sedangkan kepala sekolah sebagai orang yang meberikan bantuan dan dukungan agar guru yang bersangkutan memiliki kemampuan untuk melakukan perbaikan pembelajaran melalui manajemen kelas, guna mendapatkan pendidikan yang berkualitas.

Pendekatan merupakan langkah strategis dalam pengelolaan kelas. Dalam pengelolaan kelas, supervisor membantu guru untuk dapat memahami, memilih, menetapkandan memakai pendekatanpendekatan yang paling tepat berdasarkan pertimbangan yang matang untuk memecahkan masalah yang dimaksud. Sebagai pekerja professional pengawas/ kepala sekolah harus mendalami kerangka acuan pendekatan kelas, dan dalam penggunaannya ia harus terlebih dulu meyakinkan bahwa pendekatan yang di pilihnya untuk menangani suatu kasus pengelolaaan kelas merupakan alternatif yang terbaiksesuai dengan hakikat masalahnya.

Secara umum penyebab timbulnya masalah dalam pengelolaan kelas adalah: Kurangnya komunikasi antara pendidik dengan peserta didik, Kurangnya profesional pendidik dalam pembelajaran danrendahnya kepribadian pendidik. Dalam hal ini pengawas/ kepala sekolah haruslah melakukan pendekatan pada peserta didik, mengenali masalah peserta didik, memberikan penghargaan dan saran-saran perbaikan. Pengawas / kepala sekolah haruslah menguasai materi dan membimbing cara penyampaian tanpa ketegangan serta mengaitkannya dengan kehidupan yang dekat dengan peserta didik. Melakukan pengawasan dan pembinaan kepribadian guru/ keteladanan. 
Dua macam masalah pengelolaan kelas, yaitu : masalah individualdan masalah kelompok tidak pernah terlepas dari persoalan yang dihadapi guru. Langkah preventif ataupun kuratif yang dilakukan guru terkadang tidak membawa hasil. Maka supervisor/ kepala sekolah dituntut dapat merencanakan dan menciptakan lingkungan kelas yang tertib dan menyenangkan guna mencegah atau mengurangi jenis-jenis perilaku tertentu yang tidak diinginkan. Mengatur kembali strategi manajerial kelas dalam memulai suatu kegiatan atau cara lain yang berbeda, mengubah sifat kegiatan, mengubah pusat perhatian, atau menggunakan cara baru yang efektif dalam mengatasi masalah dalam manajemen kelas.

Tak ubahnya tipe kepemimpinan guru akan mewarnai suasana emosional di dalam kelas, tipe kepemimpinan pengawaspun akan mewarnai/ mempengaruhi emosional guru. Sebagai pengawas / kepala sekolah perlu memiliki keterampilan-keterampilan tertentu dalam bidang supervisi. Dalam hal ini pengawas/ kepala sekolah dituntut memiliki keterampilan mempimpin guru-guru yang di supervisi dalam melaksanakan tugas dan tanggung jawabnya sebagai pengajar. Mampu menciptakan situasi di mana dia dan guru-guru yang di supervise dapat bekerja sama dengan baik untuk mewujudkan manajemen kelas yang baik.

Berdasarkan pengamatan dan fakta yang ada sementara, menunjukkan bahwa masih jarang dijumpai pengawas sekolah yang memiliki karakter yang ideal sehingga menunjang dalam pelaksanaan tugas dan fungsinnya. Sebagian besar pengawas berperan seperti penonton bola yang biasa menyalahkan dan mengumpat pemain. Berikut karakter yang harus dimiliki diantaranya; jujur, professional, visioner, adil, bersahabat, cepat tanggap terhadap persoalan, dan konsisten. Berbekalkan karakter ini, supervisor akan mampu menangkap dan menjawab segenap permasalahan guru maupun kepala sekolah baik dalam hal pengelolaan kelas serta bagi kemajuan dan peningkatan mutu sekolah yang dibinanya. Kepengawasan memudahkan para guru dan kepala sekolah, memberikan rasa nyaman, kesulitan segera dibantu tanpa harus ada permintaan. 


\section{PENUTUP}

\section{A. Kesimpulan}

\section{Teoritis.}

Secara umum penyebab timbulnya masalah dalam pengelolaan kelas adalah :Kurangnya komunikasi antara pendidik dengan peserta didik, Kurangnya profesional pendidik dalam pembelajaran dan rendahnya kepribadian pendidik.

Langkah preventif ataupun kuratif yang dilakukan guru mengatasi masalah individualdan masalah kelompokterkadang tidak membawa hasil. Maka supervisor/ kepala sekolah dituntut dapat merencanakan dan menciptakan lingkungan kelas yang tertib dan menyenangkan. Mengatur kembali strategi manajerial kelas guna mengatasi masalah dalam manajemen kelas.

Pendekatan merupakan langkah strategis dalam pengelolaan kelas. Dalam pengelolaan kelas, supervisor membantu guru untuk dapat memahami, memilih, menetapkandan memakai pendekatanpendekatan yang paling tepat berdasarkan pertimbangan yang matang untuk memecahkan masalah yang dimaksud.

\section{Praktis}

Pengawasan yang dilakukan oleh Supervisor sangat minim dan belum memberikan kontribusi yang berarti terhadap kemampuan dan upaya guru dalam manajemen kelas. Banyak pengawas sekolah belum memiliki karakter ideal yang mendukung pelaksanaan tugas dan fungsinnya. Peran kepala sekolah sebagai pengawas lebih mendukung dan menguntungkanbagi para guru, kepala sekolah lebih mengenal situasi, kondisi dan strategi yang tepat untuk memberikan bantuan pada guru yang bersangkutan. Kontribusi supervisi kepala sekolah terhadap upaya guru dalam manajemen kelas menjadi dorongan moral bagi guru untuk lebih yakin dalam melangkah dan mengambil kebijakan. 


\section{Daftar Rujukan}

Ahmad Rohani. 2004. Mengelola Kelas Yang Efektif, Dalam Buku Pengelolaan Pengajaran. Jakarta. Rineka Cipta.

Amatembun, N. A. 1992. Manajemen Kelas. IKIP Bandung.

Arikunto, Suharsimi. 1990. Manajemen Pengajaran Secara Manusiawi. Jakarta: PT Rineka Cipta

Cony Semiawan, Pendekatan Ketrampilan Proses, Bagaimana Mengaktifkan Peserta didik Dalam Belajar(Jakarta: Grasindo, 1992), hlm. 64.

Departemen Pendidikan dan Kebudayaan. 1982. Buku II: Modul Pengelolaan Kelas. Jakarta: Departemen Pendidikan dan Kebudayaan, Direktorat Jenderal Pendidikan Tinggi, Proyek Pengembangan Institusi Pendidikan Tinggi.

Depdikbud. 1983. Pengelolaan Kelas. Jakarta: Direktorat lenderal Pendidikan Tinggi

Djamarah, Syaiful Bahri. 2005. Guru dan Anak Didik Dalam Interaksi Edukatif. Jakarta: PT Rineka Cipta,

Djamarah, Syaiful Bahri. 2010. Pengelolaan Kelas. Jakarta. Rineka Cipta. Djamarah, Syaiful. 2006. Strategi Belajar Mengajar. Jakarta: Rineka Cipta Evertso, Carolin dan Edmynd T Emmer, Manajemen Kelas Untuk Guru Sekolah Dasar, Jakarta : Kencana, 2011.

Ghoni, Djunaidi. 2008 Penelitian Tindakan Kelas. Malang: UIN Malang

Gordon, Thomas. 1990. Guru Yang Efektif: Cara Untuk Mengatasi Kesulitan Dalam Belajar. Jakarta: Rajawali

Harsanto, Radno. 2007. Pengelolaan Kelas yang Dinamis. Yogyakarta: Kanisius.

Kazhim, M Nabil, Mendidik Anak Tanpa Kekerasan, Jakarta : Pustaka Al Kautsar, 2010.

Majid, Abdul. 2005, Perencanaan pembelajaran.. Rosda karya. Bandung

M. Entang clan T. Raka Joni. 1983. Pengelolaan Kelas. Jakarta: Proyek Pengembangan Pendidikan Tenaga Kependidikan Depdikbud Direktorat Jenderal Pendidikan Tinggi.

Mulyasa. 2010. Menjadi Guru Profesional Menciptakan Pembelajaran Kreatif dan Menyenangkan. Bandung. Rosdakarya.

Mulyadi, Classroom Manajemen, UIN Malang Press, 2009. 
Popham, W, James. Teknik Mengajar Secara Sistematis. 1992. Rineka cipta. Jakarta

Partin, L Ronald. 2009 Kiat Nyaman Mengajar Di Dalam Kelas, Jilid 1. Jakarta : Indek

Partin, L Ronald. 2009 Kiat Nyaman Mengajar Di Dalam Kelas, Jilid 2. Jakarta : Indek

Roestiyah. 1994. Masalah Pengajaran. Jakarta: PT Rineka Cipta.

Rachman, Maman. 1998. Manajemen Kelas. Jakarta: Departemen Pendidikan dan Kebudayaan Direktorat Jenderal Pendidikan Tinggi.

Rohani, Ahmad. Pengelolaan Pengajaran. Jakarta : Rineka Cipta, 2010.

Rusyan, Tabrani, A, 2008, Etos Kerja Dalam Meningkatkan Produktivitas Kinerja Guru, Jakarta Timur, PT. Intermedia Cipta Nusantara.

Sagala, Syaiful. 2006. Konsep Dan Makna Pembelajaran. Bandung: Alfabeta

Sekar Ayu Kusuma. 2007. Strategi Pembelajaran Aktif. Yogyakarta: CTSD

Setiawan, Conny, dkk. Pengelolaan Kelas. 1985. Gramedia. Jakarta

Seifert, Kelvin. 2008. Manajemen Pembelajaran $\mathcal{E}$ Instruksi Pendidikan. Yogyakarta. IRCiSoD.

Sudjana, Nana \& Ibrahim. 2011. Penelitian Dan Penilaian Pendidikan. Bandung : Sinar Baru.

Suryana, Asep. 2007. Manajemen Kelas. FIP UPI Bandung

Sumiati, Azra, 2008, Metode Pembelajaran, Bandung, CV. Wacana Prima.

Yamin, Martinis, Manajemen Pembelajaran Kelas. Jakarta : GP Press, 2009 